\section{Inconstancy of drinking bursts during schedule-induced polydipsia}

\author{
NORMAN HYMOWITZ and EARL X. FREED \\ Alcohol Research Laboratory, V.A. Hospital, Lyons, N.J. 07939
}

Cumulative records of 16 rats from three previous studies of schedule-induced polydipsia were divided into quarters, and the mean number of licks per pellet for each quarter was calculated. Analysis of variance revealed a significant "quarters" effect, interpreted as indicating that the number of licks per pellet decreased as the session progressed. This finding was discussed in terms of methodological considerations for research on the effects of "meal" size on schedule-induced polydipsia.

Falk (1967) reported that schedule-induced polydipsia (SIP) was inversely related to the number of pellets delivered per interval. Rats responding on variable-interval 1 -min (VI-1) and VI-2 schedules of reinforcement drank less water when the number of pellets per reinforcement (meal) was increased from one to two. Inspection of cumulative records attributed reduced fluid intake during the multipellet condition to omissions of postpellet drinking bursts. Subsequent research on this topic (Flory, 1971; Hawkins, Everett, Githens, \& Schrot, 1970) yielded similar results. However, these researchers recognized an inherent difficulty in Falk's experimental design. By holding constant the total number of pellets delivered in a session, the one-pellet-per-meal treatment perforce resulted in twice as many meals, hence, drinking opportunities, than the two-pellet-per-meal treatment. The greater water intake during the one-pellet condition may have been due, at least in part, to the greater number of drinking occasions.

Hawkins et al reanalyzed Falk's data in terms of estimated fluid ingestion rates. If the animals had as many drinking opportunities during the two-pellet treatment as during the one-pellet treatment, the animals would have consumed more water per interval during the two-pellet condition. That is, for a total of six comparisons, drinking rates for the two-pellet condition were higher in four, approximately equal for one, and lower for only one. This analysis is based on the assumption that fluid intake remains constant throughout the course of a session. However, if water intake declines as the session progresses, there would be a bias in favor of more drinking for the multipellet treatment.

Since "meal size" has played an important role in contemporary explanations of SIP (Denny \& Ratner, 1970; Falk, 1969, 1970), it seemed desirable to test this assumption. Flory (1971) examined this issue and concluded that although there was a slight decline in drinking through a session, it was not enough of a decline to bias recalculations of the data seriously. However, Flory compared licks per interval from the first half of a session to licks per interval thoughout the entire session, an analysis that may have masked the overall magnitude of the decline in licking. A more sensitive analysis must at least include a comparison between licks per interval during some initial portion of the session to licks per interval during a final portion.

METHOD
One-hour cumulative records of 16 rats from three previous studies (Freed \& Lester, 1969; Hymowitz, Freed, \& Lester, 1970; Freed \& Hymowitz, 1972) were divided into quarters, and the mean number of licks per pellet for each quarter was calculated. This number of licks required to move the cumulative recorder response pen $1 \mathrm{~mm}$ and then measuring the length of each was accomplished by determining the postpellet drinking burst.

Despite many procedural differences between the three studies (i.e., size of animals, percent of body weight loss, use of licking or leverpressing as the operant upon which the delivery of $45-\mathrm{mg}$ Noyes pellets was contingent, and the use of stimuli to indicate the availability of reinforcers), the polydipsia generated in the various experiments was quite similar. In all of the studies, the interpellet interval was $60 \mathrm{sec}$.

RESULTS AND DISCUSSION

Individual $\mathrm{S}$ data, as well as a brief description of each experiment, are shown in Table 1. Analysis of variance of the data from all 16 animals revealed a significant "quarters" effect $(F=20.32, \mathrm{df}=3 / 48, p<.005)$. As the session progressed, the number of licks per pellet decreased (see Fig. 1).

These data clearly indicate that polydipsic postpellet water consumption decreased as the session progressed. An earlier paper (Freed, Carpenter, \& Hymowitz, 1970) indicated a similar decline in schedule-induced alcohol consumption. However, in the latter case, the effect was noticeable even in casual inspection of the cumulative record. The present findings are also in general agreement with previous studies on the duration of postpellet drinking bursts during schedule-induced water intake (Falk, 1966; Keehn \& Colotla, 1970). These studies reported that drinking bursts during the beginning of experimental sessions were greater than those that followed. However, drinking bursts during the remainder of the session remained relatively constant. The present study emphasizes the continuous decrease in the duration of drinking bursts throughout the session.

Table 1

Mean Number of Licks Per Pellet for Quarters of 1-H Experimental Session

\begin{tabular}{|c|c|c|c|c|c|}
\hline \multirow[b]{2}{*}{ Experiment } & \multirow[b]{2}{*}{ Animal } & \multicolumn{4}{|c|}{ Session Quarters } \\
\hline & & First & Second & Thind & Fourth \\
\hline $\begin{array}{l}\text { A: Freed \& Lester (1969): } \\
\text { FI } 60,80 \% \text { body weight, } \\
\text { Day } 9\end{array}$ & $\begin{array}{l}\mathbf{5 0 1} \\
\mathbf{5 0 3} \\
\mathbf{5 7 0} \\
\mathbf{5 7 1} \\
\mathbf{5 7 2}\end{array}$ & $\begin{array}{r}116.51 \\
170.48 \\
140.48 \\
99.49 \\
139.73\end{array}$ & $\begin{array}{r}80.63 \\
201.00 \\
138.75 \\
92.25 \\
101.48\end{array}$ & $\begin{array}{r}67.76 \\
180.22 \\
115.16 \\
88.39 \\
104.18\end{array}$ & $\begin{array}{r}49.54 \\
170.06 \\
103.65 \\
84.90 \\
115.43\end{array}$ \\
\hline $\begin{array}{l}\text { B: Freed \& Lester (1969): } \\
\text { FI } 60 \text {, licking is operant } \\
\text { response, } 80 \% \text { body } \\
\text { weight, Day } 10\end{array}$ & $\begin{array}{l}651 \\
654 \\
653\end{array}$ & $\begin{array}{l}189.38 \\
170.74 \\
271.50\end{array}$ & $\begin{array}{l}171.68 \\
140.48 \\
224.70\end{array}$ & $\begin{array}{l}178.55 \\
112.50 \\
162.30\end{array}$ & $\begin{array}{l}153.45 \\
110.25 \\
147.30\end{array}$ \\
\hline $\begin{array}{l}\text { C: Hymowitz, Freed, \& } \\
\text { Lester (1970): FI } 60 \\
\text { with cues, 80\% body } \\
\text { weight, Day } 10\end{array}$ & $\begin{array}{l}660 \\
661 \\
662\end{array}$ & $\begin{array}{l}138.49 \\
152.48 \\
243.19\end{array}$ & $\begin{array}{l}101.25 \\
125.25 \\
237.30\end{array}$ & $\begin{array}{r}97.50 \\
104.25 \\
193.54\end{array}$ & $\begin{array}{l}102.38 \\
112.99 \\
119.10\end{array}$ \\
\hline $\begin{array}{l}\text { D: Freed \& Hymowitz } \\
\text { (1972): FFI 60, } 70 \% \\
\text { body weight, Day } 12\end{array}$ & $\begin{array}{l}\mathbf{7 5 6} \\
\mathbf{7 5 5} \\
\mathbf{7 5 3} \\
\mathbf{7 5 2} \\
\mathbf{7 5 7}\end{array}$ & $\begin{array}{r}184.99 \\
129.75 \\
74.48 \\
85.50 \\
89.25\end{array}$ & $\begin{array}{r}166.24 \\
111.00 \\
58.24 \\
67.73 \\
68.48\end{array}$ & $\begin{array}{r}139.24 \\
89.74 \\
49.73 \\
60.75 \\
59.74\end{array}$ & $\begin{array}{r}138.75 \\
96.98 \\
47.66 \\
49.24 \\
\mathbf{5 9 . 2 5}\end{array}$ \\
\hline
\end{tabular}



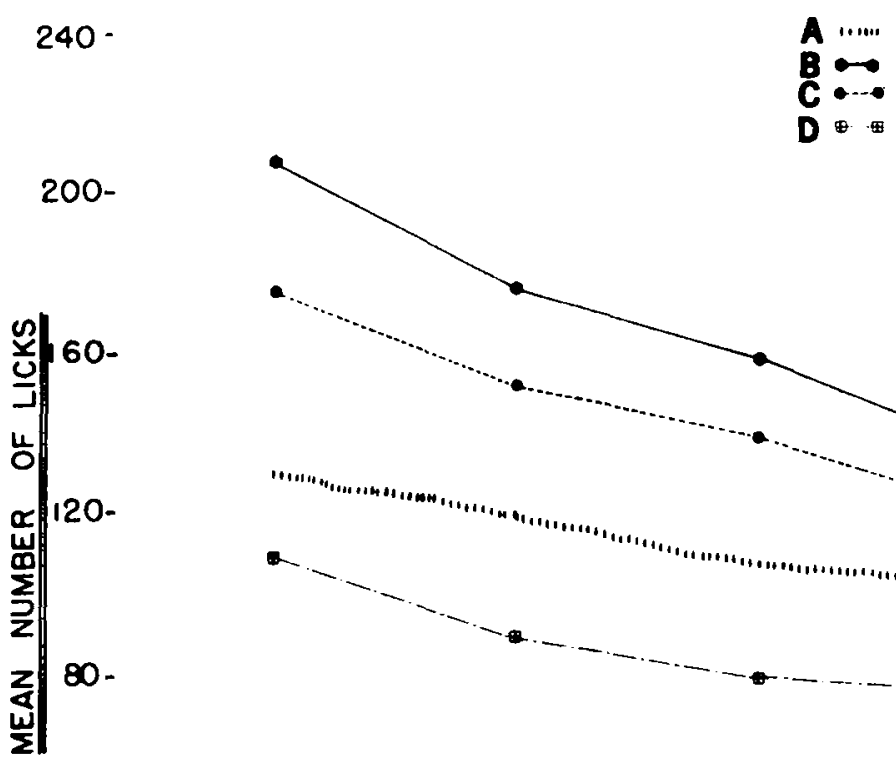

40 -

o.

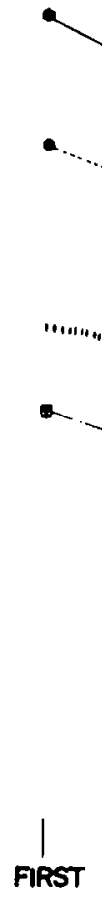

to the issue of omission of drinking bursts during the multipellet condition, however, has not been forthcoming. That SIP decreases to a significant degree as the session ensues is a finding that merits consideration.

\section{REFERENCES}

DENNY, M. R., \& RATNER, S. C Comparative psychology. Homewood, Ill: Dorsey Press, 1970.

FALK, J. L. Analysis of water and $\mathrm{NaCl}$ solution acceptance by schedule induced polydipsia. Journal of the Fxperimental Analysis of Behavior, 1966, 9, $111-118$.

FALK, J. L, Control of schedule-induced polydipsia: Type, size, and spacing of meals. Journal of the Fixperimental Analysis of Behavior, 1967, 10,199-206.

FALK、J. L. Conditions producing psychogenic polydipsia in animals. Annals of the New York Academy of Sciences, $1969,157,569-593$.

FALK, J. L. The nature and determinants of adjunctive behavior. Physiolony \& Behavior, $1970,6,577-588$.

FLORY, R. K. The control of schedule-induced polydipsia: Frequency and magnitude of reinforcement. Learning \& Motivation, 1971, 2, 215-227.

FREED, E. X.. CARPENTF. . J. A., \& HYMOWITZ, N. Acquisition and extinction of schedule-induced polydipsic consumption of alcohol and water. Psychological Revorts, 1970, 26. 915-922.

FREED, E. X., \& HYMOWIT\%. R. The effects of schedule, percent bodt weight. and reinfores magniture on the acquisition of schedulp-induced polydipsia. Psychological Roports. 1472. 31, 95-101

Fig. 1. Mean number of licks per quarter of polydipsic session.

It should be noted that Flory (1971) and Hawkins et al (1970) also compared licks per interval for the twoand one-pellet conditions, with number of intervals held constant. At intervals of $60 \mathrm{sec}$ or less, Flory reported few, if any, differences in licks. At greater intervals, more licking occurred during the two-pellet condition. Falk (1969) also reported more licking for the two-pellet condition at extremely long intervals. Hawkins et al, however, found more drinking during the two-pellet treatment at intervals of $60 \mathrm{sec}$ as well as $120 \mathrm{sec}$. These studies compared water intake during some initial portion of a lengthy one-pellet-per-meal session and a complete two-pellet-per-meal session of short duration. The validity of these data rests on the assumption that lick rate is independent of session length. Empirical support for this assumption is highly desirable.

It is clear, then, that the relationship between SIP and meal size is more complex than earlier reports had indicated. The experimental treatment of this problem, by and large, utilizes a methodology that is beset with many problems. Studies that employed different methodologies (Keehn, 1970; Freed \& Hymowitz, 1972) yielded findings more compatible with Falk's (1967) initial report of an inverse relationship between meal size and SIP. Attention
FREED. E. X.. \& I,ESTER, D. Schedule-induced consumplion of ethanol: Calories or chemotherapy? Physiology \& Behavior, 1969,5.555-560. HAWKINS, T. D., EVERE'T. P. B. GITHENS, S. H., \& SCHRUT, J. F Adjunctive drinking: A functional analysis of water and alcohol ingestion. In schedule-induced and schedula depcndent phenomona. Vol. 1. Toronts: Addiction Research Foundation, 1970. Pp. 227-286.

HYMOWITZ, N. FREFD, E. X. \& LESTER, D. The independence" of barpressing and schedule-induced drinking. Psychonomic Scionit. 1970.20. 45-46.

KEEHN, J. D. Beyond the law of effect. In schedule-induced and schrdule dependent phenomena. Vol. 1. Toronto: Addiction Research Foundation, 1970. Pp. 137-186.

KEEHN, J. D., \& COLOTLA. V. A. Predictability of schedule-induced drink durations. Psychonomic Science, 1970. $18,297-298$. 